\title{
Biophysical characteristics and thermophysiological responses at the inflection point in deep body temperature for individuals with high or low aerobic fitness
}

\author{
Ella F Walker,, Jo Corbett, James R House, Michael J Tipton \\ From 15th International Conference on Environmental Ergonomics (ICEE XV) \\ Portsmouth, UK. 28 June - 3 July 2015
}

\section{Introduction}

Endurance training increases aerobic fitness, improves thermoregulatory function [1] and exercise tolerance in the heat [2]. However, studies comparing individuals of high and low aerobic fitness during exercise in the heat are often confounded by differences in body weight and body composition [3]. It is also disputed if using the relative work rate to standardise exercise intensity is appropriate $[4,5]$ as individuals with higher aerobic fitness will be working at a higher absolute work rate with increased heat production. This study examined the influence of aerobic fitness on biophysical characteristics and thermophysiological responses when moving from compensable to uncompensable conditions, at matched relative and absolute work rates, under conditions of high and low humidity.

\section{Methods}

Eight high (HI) $\left(\mathrm{VO}_{2 \max }=58.73[6.28] \mathrm{mL} \cdot \mathrm{kg}^{-1} \cdot \mathrm{min}^{-1}\right)$ and eight low aerobic fitness (LO) (46.53[6.73] mL. $\mathrm{kg}^{-1}$. $\mathrm{min}^{-1}$ ) males, matched for body mass, body surface area and \% body fat volunteered. LO exercised at $60 \mathrm{~W}$ (ABS) in a hot-humid $\left(28^{\circ} \mathrm{C}\right.$ starting temperature, $80 \%$ rh $[\mathrm{HH}])$ and hot-dry $\left(34{ }^{\circ} \mathrm{C}\right.$ starting temperature, $20 \%$ rh [HD]) environment. HI completed the same trials, plus an additional trial in each condition to match the relative intensity of the $\mathrm{LO}$ group exercising at $60 \mathrm{~W}$ (REL). $T_{d b}$ was incremented after 60 minutes of exercise until an inflection in rectal temperature $\left(\mathrm{T}_{\text {reinfl }}\right) . \mathrm{T}_{\mathrm{db}}$, $\mathrm{T}_{\mathrm{re}}$, upper back sweat rate $\left(\mathrm{SR}_{\mathrm{Back}}\right)$ and forearm skin

\footnotetext{
* Correspondence: ella.walker@port.ac.uk

Extreme Environments Laboratory, Department of Sport and Exercise Science, University of Portsmouth, Portsmouth, UK
}

blood flow $(\mathrm{SkBF})$ were measured at the $\mathrm{T}_{\text {reinfl. }}$ Data were analysed by mixed-model ANOVA, with post hoc analysis by paired (effect of humidity) or independent t-tests (effect of fitness).

\section{Results}

$\mathrm{T}_{\mathrm{db}}$ at $\mathrm{T}_{\mathrm{re}}$ inflection was lower in the $\mathrm{HH}$ condition in both ABS $(\mathrm{p}<0.001)$ and REL $(\mathrm{p}<0.001)$ conditions. Additionally, during REL trials, $\mathrm{T}_{\mathrm{db}}$ at $\mathrm{T}_{\text {reinfl }}$ was lower for $\mathrm{HI}$ than $\mathrm{LO}$ in the $\mathrm{HH}$ condition $(\mathrm{p}=0.013)$. $\mathrm{T}_{\mathrm{re}}$ was lower in $\mathrm{HI}$ than $\mathrm{LO}$ at the $\mathrm{T}_{\text {reinfl }}$ in the $\mathrm{HH}$ condition during ABS trials $(p=0.010)$, with no effect of fitness or humidity condition in REL trials. HI had higher $\mathrm{SR}_{\text {Back }}$ at the $\mathrm{T}_{\text {reinfl }}$ in in both ABS trials $(\mathrm{HH}, \mathrm{p}=$ 0.030; HD, $\mathrm{p}=0.005)$ and REL trials $(\mathrm{HH}, \mathrm{p}=0.001$; HD condition, $\mathrm{p}<0.001)$. SkBF at the $\mathrm{T}_{\text {reinfl }}$ not differ between any of the trials $(\mathrm{p}>0.05)$.

\section{Discussion}

There was no effect of fitness on $\mathrm{T}_{\mathrm{db}}$ at $\mathrm{T}_{\text {reinfl }}$ at $\mathrm{ABS}$, but $\mathrm{HI}$ had a lower $\mathrm{T}_{\mathrm{db}}$ at $\mathrm{T}_{\text {reinfl }}$ at REL in the $\mathrm{HH}$ condition reflecting the higher metabolic heat production and lower capacity for evaporative heat loss. The difference in $\mathrm{T}_{\mathrm{re}}$ at the inflection point between $\mathrm{HI}$ and $\mathrm{LO}$, in the $\mathrm{HH}$ environment, may be due to the need to maintain a gradient for heat exchange from core to shell under conditions where an increased SR is not sufficient to maintain heat loss. Nonetheless, $\mathrm{HI}$ individuals have been shown to tolerate higher $\mathrm{T}_{\mathrm{c}}$ temperatures than $\mathrm{LO}$ counterparts when exercising in the heat [2] and the practical significance of the lower $\mathrm{T}_{\mathrm{re}}$ at the inflection point is unclear. 


\section{Conclusion}

Despite improved thermoregulatory function, when body weight and body composition are controlled, aerobic fitness does not offer any benefit in terms of the biophysical conditions eliciting the transition to uncompensable heat stress when exercising a given ABS. Moreover, the $\mathrm{T}_{\text {reinfl }}$ may occur at a lower $\mathrm{T}_{\mathrm{db}}$ in $\mathrm{HI}$ individuals when working at matched REL under conditions that limit evaporative heat loss. Finally, HI individuals may show a $\mathrm{T}_{\text {reinfl }}$ at a lower $\mathrm{T}_{\mathrm{re}}$ during exercise at a given $\mathrm{ABS}$ in $\mathrm{HH}$ conditions.

Published: 14 September 2015

\section{References}

1. Aoyagi Y, McLellan TM, Shephard RJ: Interactions of Physical Training and Heat Acclimation. Sport Med 1997, 23(3):173-210.

2. McLellan TM: The importance of aerobic fitness in determining tolerance to uncompensable heat stress. Comp Biochem Physiol A Mol Integr Physiol 2001, 128(4):691-700.

3. Jay O, Bain AR, Deren TM, Sacheli M, Cramer MN: Large differences in peak oxygen uptake do not independently alter changes in core temperature and sweating during exercise. Am J Physiol Regul Integr Comp Physiol 2011, 301(3):832-841.

4. Gass GC, McLellan TM, Gass EM: Effects of prolonged exercise at a similar percentage of maximal oxygen consumption in trained and untrained subjects. Eur J Appl Physiol Occup Physiol 1991, 63(6):430-435.

5. Saltin B, Hermansen LJ: Esophageal, rectal, and muscle temperature during exercise. Appl Physiol 1966, 21(6):1757-1762.

6. Ichinose-Kuwahara T, Inoue $Y$, Iseki Y, Hara S, Ogura Y, Kondo N: . Exp Physiol 2010, 95(10):1026-1032.

doi:10.1186/2046-7648-4-S1-A51

Cite this article as: Walker et al:: Biophysical characteristics and thermophysiological responses at the inflection point in deep body temperature for individuals with high or low aerobic fitness. Extreme Physiology \& Medicine 2015 4(Suppl 1):A51.

\section{Submit your next manuscript to BioMed Central} and take full advantage of:

- Convenient online submission

- Thorough peer review

- No space constraints or color figure charges

- Immediate publication on acceptance

- Inclusion in PubMed, CAS, Scopus and Google Scholar

- Research which is freely available for redistribution

Submit your manuscript at www.biomedcentral.com/submit 